Llewellyn, Karl, and E. Adamson Hoebel.

1941. The Cheyenne Way: Conflict and Case Law in Primitive Jurisprudence. Norman: University of Oklahoma Press.

Lobsenz, James E.

1982. 'Dependent Indian Communities': a Search for a Twentieth Century Definition. Arizona Law Review 24(1): 4-5.

Pospisil, Leopold.

1971. Anthropology of Law: A Comparative Theory. New York: Harper and Row.

Schnader, William A.

1967. A Short History of the Preparation and Enactment of the Uniform Commercial Code. University of Miami Law Review 22: 1-12.

Steward, Julian H.

1938. Basin Plateau Socio-Political Groups. Bureau of American Ethnology, Bulletin

120. Washington, DC: Bureau of American Ethnology.

Turner, Allen C.

1987. Evolution, Assimilation, and State Control of Gambling in Indian Country: Is

Cabazon v. California an Assimilationist Wolf in Preemption Clothing? Idaho Law Review 24: 317-338.

1992. Prolegomenon to a Forensic Cultural Anthropology. American Journal of Trial Advocacy 16: 391-415.

Twining, William.

1973. Karl Llewellyn and the Realist Movement. London: Weidenfeld and Nicolson.

van Willigen, John.

1991. Anthropology in Use: A Source Book on Anthropological Practice. Boulder: Westview.

Wilkinson, Charles F.

1987. American Indians, Time, and the Law: Native Societies in a Modern Constitutional Democracy. New Haven: Yale University Press.

\title{
Becoming West Indian: Culture, Self, and Nation in St. Vincent, by Virginia Heyer Young. Washington and London: Smithsonian Institution Press, 1993, 229 pp.
}

\section{Reviewed by Helen I. Safa, Professor of Anthropology and Latin American Studies, University of Florida.}

National identity has long been problematic in the small, open and dependent islands of the Caribbean, where a history of slavery and colonialism have brought about marked racial, religious and linguistic differences. Formation of a national identity was particularly difficult in the English-speaking countries of the Caribbean, where absentee plantation ownership predominated, and slaves generally were more prevalent than in most of the Hispanic Caribbean colonies. In the Hispanic Caribbean, by contrast, the 
planter elite developed a strong sense of identification with the colonizing powers, and miscegenation between the white elite and black slaves led to the rapid rise of an intermediate free colored group (S. Mintz 1974; F. Knight 1990).

In Becoming West Indian, Young challenges the generally held view that national identity is only weakly formed in the English-speaking Caribbean. Young presents an ethnohistorical study of St. Vincent, a small island in the eastern Caribbean that remained under British rule until it was granted political independence in 1969. A major part of her book is devoted to an ethnographic study of a rural village conducted in 1972, complemented by two shorter field trips in the 1980s, and by archival research.

She argues that despite racial and class divisions, the village has a well-established Creole culture characteristic of the English-speaking Caribbean. She generalizes from this village to the whole island nation. Young appears to contradict herself, however, when in referring to the village she notes that "although cultural systems, thoughts and values are shared, there is low social cohesion, marked differences in living standards, and recognition of status differences" (p. 92). Shared culture should be expressed in some form of village solidarity, but there is no solidarity. Young's notion of rural culture as the basis of national identity is difficult to accept, and it is equally difficult to consider the village as "representative in some degree of the nation" (ibid.). Despite some mobility from the village peasantry into the urban middle class in recent years, the class and racial divisions of the village clearly are more marked in the capital, the center of the island's economy and home to its elite.

The disdain with which villagers regarded the national carnival, and their recreation of a more "authentic" version, suggest a sharp cultural divide between rural and urban residents, even on so small an island as St. Vincent. The peasantry, who form the bulk of the village population, probably do share a common culture born of years of struggle to obtain land and to make a living from it, first in arrowroot and now in banana production. But there is little evidence that this culture is shared with the elite, who remain quite Eurocentric in their orientation.

Young notes that in the colonial period, St. Vincent had the highest degree of absentee plantation owners of all the Windward Islands. Owner absenteeism, combined with a strong profit orientation, resulted in abysmal conditions on the sugar estates. As a result, emancipation was followed by a massive emigration of former slaves to work in Trinidad, Guiana, and more recently, to the U.S., especially New York City. The impact of emigration on national identity deserves more attention than Young gives it. An important effect of emigration may be to reinforce a sense of national unity in opposition to other islanders met abroad, while also serving to create a pan-West Indian identification in others. Because of its poverty and large-scale emigration, St. Vincent is a classic example of a "remittance society," in which all classes are dependent on income from abroad, as Young's data demonstrate. Remittances enabled leaseholders to finally acquire land from reluctant estate owners, who preferred to let their land lie idle rather than divide it up; Young notes that even today land is still concentrated among large owners.

She also points to the prestige of British political culture as a symbol of national identity in St. Vincent, despite the fact that property requirements for voting disenfranchised large segments of the population for much of their history. She claims it was the respect for British culture that caused the slaves to side with the planters against the Black Caribs, who were themselves descendants of Maroons (runaway slaves) and Carib Indians who had been granted land rights in St. Vincent by the British and French. 
The abrogation of these land rights led to war in 1795 and the defeat of the Black Caribs, which forced their mass relocation first to Roatan and then British Honduras (now Belize).

Young attempts to explain the slaves' allegiance to their masters by depicting plantation society as a "source of cultural identification" for slaves, which is difficult to comprehend given their oppressed status on the estates. The peasantry in the Englishspeaking Caribbean may have come to admire the law and order established by Westminster-style democratic politics compared to the violence in Haiti, Cuba, the Dominican Republic, and other countries. Admiration for British culture also served to maintain a Eurocentric orientation, however, especially among the elite. Eurocentrism almost certainly stifled the sense of national identity and denigrated the African-derived components of Caribbean culture. A sense of national identity may be emerging in St. Vincent among the peasantry, but it does not appear to be shared with the elite. Thus Young's challenge to the prevailing view that national identity is weak in the Englishspeaking Caribbean remains unconvincing, at least to this reader.

\title{
References Cited
}

Knight, Franklin W.

1990. The Caribbean: The genesis of a fragmented nationalism (2nd ed.). New York: Oxford University Press.

Mintz, Sidney W.

1974. Caribbean Transformations. Chicago: Aldine.

\section{Cultivating Crisis: The Human Costs of Pesticide Use in Latin America, by Douglas L. Murray; University of Texas Press (1994); xiv, 177 pp.}

\author{
Reviewed by William M. Loker, Department of Sociology, \\ Anthropology and Social Work, Mississippi State University.
}

Cultivating Crisis came to me for review at a time when I had been reading a couple of other books on related themes (S. Stonich 1993, J. Vandermeer and I. Perfecto 1995) as well as reflecting on my own impressions gained from recent anthropological fieldwork in Central America. All three books--Murray's, Stonich's and Vandermeer and Perfecto's-deal with the political ecology of agrarian crisis in Central America. My recent fieldwork in Honduras put me dramatically back in touch with that crisis after a ten-year absence. What is evident from these books, and from my own experience, is that despite an overall reduction in political violence, which has allowed Central America to vanish from the headlines of U.S. newspapers, the region is gripped in its most serious crisis in recent history. This crisis is driven by multiple factors including population growth, extreme levels of social and economic inequality, and the exhaustion of both contemporary 